\title{
Constructive controversy dan inkuiri terbimbing sesuai representasi tetrahedral pembelajaran kimia ditinjau dari kemampuan berpikir kritis
}

\author{
Siti Khoirun Annisak *, Nurma Yunita Indriyanti, Bakti Mulyani \\ Universitas Sebelas Maret. Jalan Ir. Sutami No.36 A, Pucangsawit, Kota Surakarta, 57126, Indonesia \\ * Coressponding Author. E-mail: khoir_annisak@yahoo.com
}

Received: 20 July 2018; Revised: 28 November 2018; Accepted: 29 March 2019

\begin{abstract}
Abstrak
Materi kimia kelarutan dan hasil kali kelarutan (Ksp) merupakan salah satu materi yang sulit sehingga dibutuhkan kemampuan berpikir kritis. Inovasi pembelajaran untuk meningkatkan kemampuan berpikir kritis sangat penting. Penelitian ini bertujuan untuk mengetahui: (1) pengaruh penerapan model pembelajaran Constructive Controversy (CC) dan inkuiri terbimbing berdasarkan representasi tetrahedral kimia terhadap prestasi belajar siswa pada materi Ksp; (2) pengaruh kemampuan berpikir kritis siswa terhadap prestasi belajar siswa pada materi Ksp; (3) interaksi antara penerapan model pembelajaran CC dan inkuiri terbimbing berdasarkan representasi tetrahedral kimia dengan kemampuan berpikir kritis terhadap prestasi belajar siswa pada materi Ksp. Penelitian ini merupakan penelitian eksperimen semu dengan desain faktorial $2 \times 2$. Hasil penelitian menunjukkan bahwa: (1) tidak ada pengaruh penerapan model pembelajaran CC dan inkuiri terbimbing berdasarkan representasi tetrahedral kimia terhadap prestasi belajar aspek pengetahuan, sikap dan keterampilan pada materi Ksp; (2) ada pengaruh kemampuan berpikir kritis siswa terhadap prestasi belajar siswa aspek pengetahuan tetapi tidak ada pengaruh terhadap aspek sikap dan keterampilan pada materi Ksp; (3) tidak ada interaksi antara penerapan model pembelajaran CC dan inkuiri terbimbing berdasarkan representasi tetrahedral kimia dengan kemampuan berpikir kritis terhadap prestasi belajar aspek pengetahuan, sikap, dan keterampilan pada materi Ksp.
\end{abstract}

Kata Kunci: Constructive controversy (CC), inkuiri terbimbing, kemampuan berpikir kritis, representasi tetrahedral kimia, kelarutan dan hasil kali kelarutan (Ksp).

\section{Constructive controversy and guided inquiry corresponding to the tetrahedral representation chemistry learning viewed from critical thinking ability}

\begin{abstract}
Chemical subject of solubility and solubility product constant (Ksp) is one of the materials that is difficult so it needs critical thinking ability. Learning innovation to improve critical thinking skill is very important. This research aimed to determine: (1) the influence of implementing Constructive Controversy (CC) and guided inquiry learning model based on chemical tetrahedral representation towards students achievement on Ksp subject matter; (2) the influence of the student's critical thinking ability towards students achievement on Ksp subject matter; and (3) the interaction between implementing CC and guided inquiry learning model based on chemical tetrahedral representation with critical thinking ability towards students achievement on $K s p$ subject matter. This research was quasi experiment research with factorial design of $2 \times 2$. The results show that: (1) there is no influence of implementing $C C$ and guided inquiry learning model based on chemical tetrahedral representation towards students achievement of cognitive, affective, and phycomotor aspect on Ksp subject matter; (2) there is an influence of the student's critical thinking ability towards student's achievement of cognitive aspect while there is no influence of critical thinking ability toward student's achievement of affective and phycomotor aspect on Ksp subject matter; (3) there is no interaction between implementing CC and guided inquirylearning model based on chemical tetrahedral representation with critical thinking ability towards students achievement of cognitive, affective, and phycomotor aspect on Ksp subject matter.
\end{abstract}

Keywords: Constructive Controversy (CC), guided inquiry, critical thinking ability, chemical tetrahedral representation, solubility and solubility product constant (Ksp).

How to Cite: Annisak, S., Indriyanti, N., \& Mulyani, B. (2019). Constructive controversy dan inkuiri terbimbing sesuai representasi tetrahedral pembelajaran kimia ditinjau dari kemampuan berpikir kritis. Jurnal Inovasi Pendidikan IPA, 5(1), 10-22. doi:https://doi.org/10.21831/jipi.v5i1.20448 
Jurnal Inovasi Pendidikan IPA, 5 (1), 2019 - 11

Siti Khoirun Annisak, Nurma Yunita Indriyanti, Bakti Mulyani

\section{PENDAHULUAN}

Perkembangan dan kemajuan teknologi membawa dampak positif dan negatif sehingga diperlukan pendidikan moral dan lingkungan. Pendidikan mencerminkan kualitas sumber daya manusia (SDM) dari suatu bangsa. SDM di Indonesia masih tergolong rendah sehingga mencerminkan kualitas pendidikan di Indonesia rendah (Kulsum, 2013; Muhardi, 2004). Upaya pemerintah untuk mengatasi hal tersebut salah satunya dengan mengembangkan kurikulum pendidikan.

Kurikulum yang digunakan di Indonesia saat ini adalah Kurikulum 2013. Kurikulum 2013 menuntut keterlibatan siswa secara aktif dalam pembelajaran sehingga pembelajaran terpusat pada siswa (Student Centered Learning) dan bukan terpusat pada guru (Teacher Centered Learning). Akan tetapi dalam praktiknya, kurikulum ini belum diterapkan untuk semua sekolah di Indonesia sehingga tidak jarang jika kita masih menjumpai pembelajaran yang tetap terpusat kepada guru. Model pembelajaran yang digunakan sesuai dengan yang disarankan pada Peraturan Menteri Pendidikan dan Kebudayaan No 65 tahun 2013 yaitu model pembelajaran discovery learning, project-based learning, dan problem-based learning (Kementerian Pendidikan dan Kebudayaan Republik Indonesia, 2013). Selain model pembelajaran tersebut, ada model-model pembelajaran lain yang sesuai dengan Kurikulum 2013 namun belum banyak dipilih dan diterapkan di sekolah.

Model pembelajaran yang terpusat pada siswa akan membantu mempelajari ilmu kimia yang biasanya dianggap sulit. Ilmu kimia erat hubungannya dengan kehidupan (Faizah, Miswadi, \& Haryani, 2013). Perkembangan ilmu kimia dalam kehidupan dikaitkan dengan pendidikan kimia. Pendidikan kimia berperan untuk meningkatkan kualitas pembelajaran dan penelitian kimia dalam segala hal. Pembelajaran kimia yang menekankan penguasaan konsep sebaiknya menerapkan representasi segitiga kimia Johnstone (Chittleborough \& Treagust, 2007) meliputi (1) makroskopis dan kenyataan (sesuatu yang bisa dilihat, disentuh, dicium), (2) submikro (atom, molekuler, ion, dan struktur), (3) representasional simbolis (Johnstone, 2000). Penggunaan konsep segitiga Johnstone membantu siswa untuk memahami pembelajaran kimia pada tingkat makro, submikro, dan simbolis. Meskipun begitu, kebanyakan hal yang ditemui di dunia berkaitan dengan ilmu kimia sehingga perlu ditekankan dimensi baru dalam mengajarkan kimia yaitu mengenai literasi sains dan keterbatasan pemahaman masyarakat tentang peran kimia dalam kehidupan sehari-hari. Penekanan dimensi baru tersebut mengubah pembelajaran segitiga planar menjadi tetrahedral dengan puncak keempat mempresentasikan elemen manusia (Mahaffy, 2004).

Keberadaan elemen manusia akan mempermudah siswa mengaitkan kimia dengan masalah yang ada di lingkungan sekitar. Hal tersebut menjadi alasan untuk menekankan studi kasus, pembelajaran aktif, dan proyek investigasi dalam pembelajaran kimia di sekolah dengan kehidupan sehari-hari (Mahaffy, 2006). Pembelajaran kimia dengan representasi tetrahedral kimia akan mendukung penggunaan Kurikulum 2013 yang menuntut siswa agar lebih aktif dalam pembelajaran. Akan tetapi, dalam praktiknya pembelajaran kimia dengan menerapkan representasi tetrahedral kimia masih belum banyak dijumpai. Hal tersebut didukung oleh penelitian Herawati, Mulyani, dan Redjeki (2013) yang menyebutkan bahwa dewasa ini pembelajaran kimia hanya terjadi melalui dua level representasi yaitu makroskopis dan simbolis.

Di dalam pembelajaran kimia ada beberapa materi kimia yang sulit dimengerti, salah satunya materi larutan mengenai pokok bahasan Ksp. Kesulitan pada materi Ksp juga dialami oleh siswa SMA Negeri 1 Sragen, salah satu SMA favorit di Kota Sragen dan telah menerapkan kurikulum 2013. Hal tersebut didukung dengan adanya data dari BSNP mengenai rendahnya daya serap siswa pada materi tersebut yang ditunjukkan Tabel 1.

Tabel 1. Nilai Rata-rata Materi Larutan Kelas XI MIPA Semester II SMA Negeri Sragen (BSNP, 2015)

\begin{tabular}{cccc}
\hline Tahun & $\begin{array}{c}\text { Rata-rata } \\
\text { Sekolah }\end{array}$ & $\begin{array}{c}\text { Rata-rata } \\
\text { Kota }\end{array}$ & KKM \\
\hline 2013 & 77,21 & 69,64 & 75 \\
2014 & 56,54 & 47,81 & 75 \\
2015 & 63,17 & 45,89 & 75 \\
\hline
\end{tabular}

Materi Ksp bukan materi yang mudah dihafal tetapi membutuhkan pemahaman konsep. Selain itu, materi Ksp berkaitan dengan materimateri sebelumnya seperti konsep mol dan molaritas. Untuk memahami konsep materi maka diperlukan kemampuan berpikir kritis.

Kemampuan berpikir kritis setiap orang berbeda, ada yang tergolong rendah dan ada yang tergolong tinggi sehingga akan mempengaruhi tingkat pemahaman dan keaktifan seseorang 
dalam memecahkan suatu permasalahan. Hal tersebut didukung penelitian Sulistyowati, Suyatno, dan Poedjiastoeti (2014) yang menyebutkan adanya pengaruh kemampuan berpikir kritis siswa tehadap pemahaman siswa dalam menguasai suatu konsep materi. Namun dalam praktiknya guru kurang memperhatikan permasalahan tersebut. Untuk itu, diperlukan model pembelajaran yang mampu memperhatikan tingkat berpikir siswa sehingga siswa dengan kemampuan berpikir kritis rendah dapat melaksanakan proses pembelajaran dengan baik. Model yang dianggap sesuai untuk mengatasi permasalahan tersebut adalah model pembelajaran Constructive controversy (CC) dan inkuiri terbimbing.

$\mathrm{CC}$ merupakan model pembelajaran yang merupakan kombinasi pembelajaran kooperatif dengan konflik intelektual. Model CC melibatkan debat, sehingga siswa tidak hanya berargumen tetapi diharapkan dapat mempertahankan pula argumennya. Langkah pembelajaran dengan CC yaitu adanya perspektif awal, lalu meyakinkan perspektif awal, mendengarkan perspektif lain sehingga ragu pada perspektif awal, lalu pada akhirnya mencari pemahaman yang lebih baik (Mindtools, 2011).

Inkuiri terbimbing merupakan perluasan proses dicovery learning, dimana pengetahuan dan keterampilan bukan merupakan hasil mengingat dari fakta-fakta, tetapi dari proses menemukan sendiri. Inkuiri terbimbing melibatkan kemampuan peserta didik untuk mencari dan menyelidiki secara sistematis, kritis, dan logis sehingga dapat menemukan sendiri pengetahuan, sikap, keterampilan sebagai wujud perubahan perilaku (Mawarsari, 2013). Inkuiri terbimbing dapat diterapkan secara individual maupun kelompok, tentunya hal tersebut berbeda dengan $\mathrm{CC}$ yang harus diterapkan dalam kelompok.

Beberapa penelitian mengenai $\mathrm{CC}$ dan Inkuiri terbimbing dapat memberikan hasil yang baik dalam pembelajaran. Penelitian Arifah, Haryono, \& Nurhayati (2015) menunjukkan bahwa pembelajaran kimia pada materi larutan elektrolit dan non-elektrolit dengan menggunakan model Constructive Controversy dapat meningkatkan keaktifan dan prestasi belajar siswa pada materi tersebut. Penelitian Vollmer dan Seyr (2012) menyatakan bahwa penerapan Constructive Controversy berhasil mengatasi proyek inovasi, sehingga diharapkan muncul berbagai macam ide-ide baru terkait fakta-fakta yang mungkin belum terfikirkan selama ini dari berbagai sumber. Penelitian Indah dan Azizah (2014) menunjukkan bahwa penerapan model pembelajaran inkuiri terbimbing membuat aktivitas siswa meningkat. Penelitian Utami, Dasna, \& Sulistina (2012) juga menunjukkan bahwa pembelajaran kimia dengan model inkuiri terbimbing menghasilkan pencapaian belajar dan proses sains yang lebih tinggi dibandingkan model konvensional.

Berdasarkan latar belakang yang diuraikan, peneliti melakukan penelitian lanjutan mengenai efektivitas penggunaan model $\mathrm{CC}$ dan inkuiri terbimbing pada materi Ksp dengan menggunakan representasi tetrahedral kimia yang ditinjau dari kemampuan berpikir kritis siswa. Untuk itu peneliti ingin mengetahui (1) pengaruh penerapan model pembelajaran $\mathrm{CC}$ dan inkuiri terbimbing berdasarkan representasi tetrahedral kimia terhadap prestasi belajar siswa pada materi Ksp; (2) mengetahui pengaruh kemampuan berpikir kritis siswa terhadap prestasi belajar siswa pada materi Ksp; dan (3) mengetahui interaksi antara penerapan model pembelajaran CC dan inkuiri terbimbing berdasarkan representasi tetrahedral kimia dengan kemampuan berpikir kritis terhadap prestasi belajar siswa pada materi Ksp.

\section{METODE}

Penelitian ini menggunakan desain eksperimen semu dengan faktorial $2 \times 2$. Penelitian dilaksanakan pada bulan April 2017 dan dilakukan secara bertahap. Tahap pelaksanaannya seperti pada Tabel 3 .

Tabel 2. Desain Penelitian

\begin{tabular}{ccc}
\hline \multirow{2}{*}{$\begin{array}{c}\text { Model Pembelajaran } \\
(\mathrm{A})\end{array}$} & \multicolumn{2}{c}{$\begin{array}{c}\text { Kemampuan Berpikir } \\
\text { Kritis }(\mathrm{B})\end{array}$} \\
\cline { 2 - 3 } & Tinggi $\left(\mathrm{B}_{1}\right)$ & Rendah $\left(\mathrm{B}_{2}\right)$ \\
\hline $\mathrm{A}_{1}$ & $\mathrm{~A}_{1} \mathrm{~B}_{1}$ & $\mathrm{~A}_{1} \mathrm{~B}_{2}$ \\
$\mathrm{~A}_{2}$ & $\mathrm{~A}_{2} \mathrm{~B}_{1}$ & $\mathrm{~A}_{2} \mathrm{~B}_{2}$ \\
\hline
\end{tabular}

Keterangan:

$\mathrm{A}_{1}$ : Pembelajaran dengan $\mathrm{CC}$

$\mathrm{A}_{2}$ : Pembelajaran dengan inkuiri terbimbing

$\mathrm{B}_{1}$ : Kemampuan berpikir kritis tinggi

$B_{2}$ : Kemampuan berpikir kritis rendah

$A_{1} B_{1}$ : Pembelajaran dengan $C C$ pada siswa dengan kemampuan berpikir kritis tinggi

$A_{1} B_{2}$ : Pembelajaran dengan CC pada siswa dengan kemampuan berpikir kritis rendah

$A_{2} B_{1}$ : Pembelajaran dengan inkuiri terbimbing pada siswa dengan kemampuan berpikir kritis tinggi

$\mathrm{A}_{2} \mathrm{~B}_{2}$ : Pembelajaran dengan inkuiri terbimbing pada siswa dengan kemampuan berpikir kritis rendah

Penelitian ini dilaksanakan di SMA Negeri 1 Sragen pada kelas XI MIA 2 dan XI MIA 4 semester genap tahun pelajaran 2016/2017. Subjek penelitian ini adalah pada kelas XI MIA 2 dan 
XI MIA 4 SMA Negeri 1 Sragen tahun pelajaran 2016/2017 yang masing-masing berjumlah 32 siswa. Pemilihan subjek penelitian ini menggunakan teknik Cluster random sampling. Pada teknik sampling anggota sampel bukan individu-individu dari populasi, melainkan kelompok-kelompok individu (Sanjaya, 2013, p. 242).

Tabel 3. Waktu Penelitian

\begin{tabular}{cll}
\hline No. & \multicolumn{1}{c}{ Kegiatan } & \multicolumn{1}{c}{ Waktu } \\
\hline 1. & Persiapan Penelitian & Januari-Maret 2017 \\
2. & $\begin{array}{l}\text { Pelaksanaan penelitian } \\
\text { dan analisis data }\end{array}$ & April-Juni 2017 \\
3. & $\begin{array}{l}\text { Penyusunan laporan } \\
\text { dan revisi }\end{array}$ & $\begin{array}{l}\text { Oktober 2017-Juli } \\
2018\end{array}$ \\
\hline
\end{tabular}

Prosedur penelitian meliputi: (1) melakukan observasi, (2) menentukan dua kelas eksperimen untuk sampel penelitian, (3) melakukan uji coba instrumen, (4) memberikan tes kemampuan berpikir kritis kepada siswa, (5) melaksanakan penelitian, (6) memberikan tes dan nontes, (7) mengolah dan menganalisis data yang diperoleh, dan (8) menarik kesimpulan.

Teknik pengumpulan data penelitian ini menggunakan metode tes dan nontes. Metode tes digunakan untuk mengukur aspek pengetahuan siswa pada materi Ksp dan untuk mengukur kemampuan berpikir kritis siswa. Metode non tes yang digunakan dalam penelitian ini adalah angket, observasi, dan dokumentasi. Angket untuk mengukur aspek sikap, observasi digunakan untuk mengukur aspek sikap, keterampilan, dan penerapan tetrahedral kimia.

Instrumen pengumpulan data penelitian dibedakan menjadi instrumen pembelajaran dan penilaian. Instrumen pembelajaran terdiri dari silabus dan RPP. Sedangkan instrumen penilaian terdiri dari instrumen penilaian aspek pengetahuan, sikap, keterampilan, berpikir kritis, dan penerapan tetrahedral kimia selama pembelajaran. Instrumen yang digunakan diuji validitas dan reliabilitasnya, kecuali untuk silabus yang sudah tervalidasi secara langsung karena tersedia pada salinan lampiran Permendikbud Nomor 59 Tahun 2014. Uji validitas dilakukan dengan bantuan dua ahli dan dihitung menurut rumus Gregory (Gregory, 2007, p.123) sebagai berikut:

$$
\text { Content Validity }(C V)=\frac{\mathrm{D}}{\mathrm{A}+\mathrm{B}+\mathrm{C}+\mathrm{D}}
$$

Keterangan Rumus:

A : Jumlah item yang kurang relevan menurut kedua panelis

B : Jumlah item yang kurang relevan menurut panelis I dan relevan menurut panelis II
C : Jumlah item yang relevan menurut panelis I dan kurang relevan menurut panelis II

D : Jumlah item yang relevan menurut kedua panelis.

Apabila Content Validity $(\mathrm{CV})>0,7$ maka intrumen layak digunakan. Untuk instrumen aspek pengetahuan dan berpikir kritis, selain diuji validitas dan reliabilitasnya juga diuji daya beda dan tingkat kesukaran soal dengan menggunakan software ITEMAN. Dari hasil yang uji validitas dan reliabilitas diperoleh hasil bahwa instrumen yang digunakan valid dan memiliki reliabilitas tinggi.

Sebelum eksperimen dilakukan, kelas eksperimen maupun kelas uji coba diuji kemampuan awalnya. Tujuannya agar hasil eksperimen benar merupakan akibat dari perlakuan yang dibuat, bukan karena pengaruh lain. Uji keadaan awal pada sampel penelitian menggunakan uji kesetaraan rata-rata Independent Samples T-test dengan bantuan software SPSS terhadap nilai UAS I kelas XI MIA SMA Negeri 1 Sragen tahun pelajaran 2016/2017 setelah terlebih dahulu diketahui bahwa sampel berasal dari populasi normal dan homogen. Uji normalitas yang digunakan adalah Saphiro wilk dengan bantuan software SPSS. Sedangkan untuk uji homogenitas menggunakan uji Levene Statistic dengan bantuan software SPSS.

Setelah penelitian, data-data yang diperoleh dilakukan uji prasyarat yang terdiri dari uji normalitas dan homogenitas. Uji hipotesis aspek pengetahuan menggunakan statistik parametrik ANAVA dua jalan dengan frekuensi sel tak sama menggunakan bantuan software SPSS karena data berdistribusi normal dan homogen. Sedangkan uji hipotesis prestasi belajar aspek sikap dan keterampilan menggunakan uji statistik nonparametrik Kruskal Wallis dengan bantuan software SPSS karena data tidak berdistribusi normal. Taraf signifikansi $(\alpha)$ yang digunakan adalah 0,05 . Apabila hasil uji lebih besar dari 0,05 maka $\mathrm{H}_{0}$ diterima.

\section{HASIL DAN PEMBAHASAN}

Data yang didapatkan dalam penelitian ini terdiri dari data kemampuan berpikir kritis dan data prestasi belajar siswa yang meliputi aspek pengetahuan, sikap, dan keterampilan pada materi Ksp. Penelitian ini menggunakan dua macam model pembelajaran yaitu CC dan inkuiri ter-bimbing berdasarkan representasi tetrahedral kimia.

Data kemampuan berpikir kritis diperoleh dari tes berpikir kritis dan dibagi ke dalam dua kategori yaitu kemampuan berpikir kritis tinggi 
bagi siswa dengan nilai berpikir kritis $\geq$ rata-rata nilai berpikir kritis dari kedua kelas penelitian dan kemampuan berpikir kritis rendah bagi siswa dengan nilai berpikir kritis $\leq$ rata-rata nilai berpikir kritis dari kedua kelas penelitian. Dari penelitian yang telah dilakukan diperoleh nilai rata-rata kemampuan berpikir kritis gabungan kedua kelas eksperimen yaitu 61,797 Berdasarkan kriteria yang digunakan, maka 64 siswa dari 32 siswa kelas CC dan 32 siswa kelas inkuiri terbimbing yang memiliki kemampuan berpikir kritis tinggi sebanyak 31 siswa dan yang memiliki kemampuan berpikir kritis rendah sebanyak 33 siswa. Jumlah siswa dengan kemampuan berpikir kritis (KBK) tinggi dan rendah pada kelas CC dan inkuiri terbimbing dapat dilihat pada Tabel 4.

Tabel 4. Jumlah Siswa dengan KBK tinggi dan Rendah

\begin{tabular}{ccccc}
\hline \multirow{2}{*}{ KBK } & \multicolumn{2}{c}{ CC } & \multicolumn{2}{c}{ Inkuiri terbimbing } \\
\cline { 2 - 5 } & Frek. & $\%$ & Frek. & $\%$ \\
\hline Tinggi & 14 & 43,75 & 17 & 53,125 \\
Rendah & 18 & 56,25 & 15 & 46,875 \\
Jumlah & 32 & 100 & 32 & 100 \\
\hline
\end{tabular}

\section{Hipotesis Pertama}

Pengujian hipotesis pertama dilakukan untuk mengetahui pengaruh penerapan model CC dan inkuiri terbimbing berdasarkan representasi tetrahedral kimia terhadap prestasi belajar siswa pada materi Ksp. Hasil uji statistik disajikan dalam Tabel 5.

Tabel 5. Hasil Uji Statistik Hipotesis I

\begin{tabular}{lc}
\hline \multicolumn{1}{c}{ Prestasi Belajar } & Sig./Asymp Sig. \\
\hline Pengetahuan & 0,886 \\
Sikap & 0,457 \\
Keterampilan & 0,181 \\
\hline
\end{tabular}

Berdasarkan Tabel 5, hasil uji statistik parametrik pada prestasi belajar aspek pengetahuan menunjukkan nilai Sig. $(0,886)>\alpha(0,05)$ sehingga dapat disimpulkan bahwa tidak ada pengaruh penerapan model $\mathrm{CC}$ dan inkuiri terbimbing berdasarkan representasi tetrahedral kimia terhadap prestasi belajar aspek pengetahuan pada materi Ksp. Pada prestasi belajar aspek pengetahuan diperoleh nilai rata-rata yang tidak jauh berbeda untuk kelas CC $(63,125)$ dan kelas inkuiri terbimbing $(66,094)$.

Prestasi belajar dipengaruhi oleh faktor internal dan faktor eksternal. Faktor internal merupakan faktor yang timbul dari diri individu meliputi kecerdasan, fisiologis, sikap, minat, bakat, dan motivasi. Sedangkan faktor eksternal adalah faktor yang mempengaruhi prestasi belajar siswa yang berasal dari luar diri siswa melipui media pembelajaran, metode pembelajaran, keadaan sekolah, keadaan keluarga, dan lingkungan (Hamdani, 2011). Hal tersebut didukung adanya penelitian Magdalena, Mulyani, \& Van Hayus (2014, pp.162-169) yang menyatakan bahwa tidak ada pengaruh penggunaan model pembelajaran problem-based learning dan inquiry terhadap prestasi belajar siswa pada materi pokok hukum dasar kimia.

Selain itu, tidak adanya pengaruh penerapan model CC dan inkuiri terbimbing terhadap prestasi belajar siswa dikarenakan kedua model tersebut berdasarkan representasi tetrahedral kimia. Dalam pembelajaran, siswa dihubungkan dengan empat dimensi tetrahedral kimia yaitu elemen manusia, makroskopis, submikroskopis, dan simbolis. Penggunaan tetrahedral kimia akan membantu siswa untuk memahami materi.

Pada prestasi belajar aspek sikap diperoleh bahwa persentase siswa pada kelas CC yang memperoleh nilai 3 sebanyak 53,13\%, sedangkan pada kelas inkuiri terbimbing sebanyak $43,75 \%$. Siswa yang memperoleh nilai 4 pada kelas CC sebanyak 46,87\%, sedangkan pada kelas inkuiri terbimbing sebanyak 56,25\%. Berdasarkan tingginya prosentase anak yang memperoleh nilai 4, diduga bahwa kelas inkuiri lebih baik dibandingkan kelas CC. Akan tetapi, setelah dilakukan uji statistic non parametrik didapatkan nilai sig. $(0,457)>\alpha(0,05)$ sehingga dapat disimpulkan bahwa tidak ada pengaruh pembelajaran menggunakan model CC dan inkuiri terbimbing berdasarkan representasi tetrahedral kimia terhadap prestasi belajar aspek sikap pada materi Ksp. Tidak adanya pengaruh model pembelajaran terhadap aspek sikap dikarenakan sikap dipengaruhi oleh karakter siswa itu sendiri. Hal tersebut didukung oleh penelitian Rybczynski dan Schussler (2013) yang menyatakan bahwa model pembelajaran bukan faktor penting dalam pembentukan sikap siswa, tetapi karakter siswa itu sendiri yang mempengaruhi pembentukan sikapnya. Pembelajaran aspek sikap menurut Kurnianto, Masykuri, dan Yamtinah (2016, p.37) pada Kurikulum 2013 merupakan pembelajaran tidak langsung karena diintegrasikan ke dalam aspek pengetahuan saat proses belajar mengajar berlangsung. Pembentukan sikap tidak bisa dilakukan melalui beberapa kali pertemuan tetapi memerlukan waktu yang lama karena sikap terbentuk dari adanya proses pembiasaan.

Pada prestasi belajar aspek keterampilan diperoleh nilai rata-rata untuk kelas CC sebesar 
90,50 dan kelas inkuiri terbimbing sebesar 91,51. Setelah dilakukan uji statistik non-parametrik didapatkan nilai sig. $(0,181)>\alpha(0,05)$ sehingga dapat disimpulkan bahwa tidak ada pengaruh pembelajaran menggunakan model $\mathrm{CC}$ dan inkuiri terbimbing berdasarkan representasi tetrahedral kimia terhadap prestasi belajar aspek keterampilan pada materi Ksp. Penilaian keterampilan diperoleh dari nilai pengamatan selama praktikum dan nilai laporan dengan diambil nilai optimal dari keduanya. Selama pembuatan laporan, tidak menutup kemuungkinan bahwa laporan yang ditulis beberapa siswa sama. Tidak adanya pengaruh model pembelajaran terhadap prestasi belajar aspek keterampilan dikarenakan pada pembelajaran dengan model $\mathrm{CC}$ maupun inkuiri terbimbing dilakukan penilaian keterampilan dalam 1 kali pertemuan dan diambil dari materi baru yang belum pernah diperoleh. Selain itu, mengingat kemampuan awal dari kedua kelas penelitian hampir sama, dimungkinkan bahwa prestasi belajar aspek keterampilan yang dihasilkan juga hampir sama.

\section{Hipotesis Kedua}

Pengujian hipotesis kedua dilakukan untuk mengetahui pengaruh kemampuan berpikir kritis terhadap prestasi belajar siswa pada materi Ksp. Hasil uji statistik disajikan dalam Tabel 6.

Tabel 6. Hasil Uji Statistik Hipotesis II

\begin{tabular}{lc}
\hline \multicolumn{1}{c}{ Prestasi Belajar } & Sig./Asymp Sig. \\
\hline Pengetahuan & 0,000 \\
Sikap & 0,625 \\
Keterampilan & 0,445 \\
\hline
\end{tabular}

Berdasarkan Tabel 6, hasil uji statistik parametrik pada prestasi belajar aspek pengetahuan menunjukkan nilai Sig. $(0,000)<\alpha(0,05)$ sehingga dapat disimpulkan bahwa ada pengaruh kemampuan berpikir kritis terhadap prestasi belajar aspek pengetahuan pada materi Ksp. Pada prestasi belajar aspek pengetahuan, siswa dengan kemampuan berpikir kritis tingggi memiliki nilai rata-rata 79,194 sedangkan siswa dengan kemampuan berikir kritis rendah meniliki nilai ratarata 50,909. Dari nilai rata-rata tersebut menunjukkan adanya perbedaan yang signifikan antara siswa dengan kemampuan berpikir kritis tinggi dan rendah. Dengan kata lain, siswa yang memiliki kemampuan berpikir tinggi cenderung memiliki prestasi belajar aspek pengetahuan yang lebih baik dibandingkan dengan siswa yang memiliki kemampuan berpikir kritis rendah. Kemampuan berpikir kritis dapat memberikan kontribusi prestasi belajar yang positif dalam pembelajaran kimia (Pusporini, Ashadi, \& Sarwanto, 2012, pp.34-43). Kemampuan berpikir kritis siswa yang tinggi akan mendorong siswa untuk memiliki rasa ingin tahu yang besar dalam belajar dan berusaha berpikir logis dalam rangka memecahkan masalah dengan bertanya maupun mencari solusi sendiri (Hofreiter, Monroe, \& Stein, 2007, pp.149-157). Sehingga dalam pembelajaran siswa dengan kemampuan berpikir kritis tinggi akan cenderung lebih aktif dibandingkan dengan siswa yang memilki kemampuan berpikir kritis rendah.

Pada prestasi belajar aspek sikap, persentase siswa yang memiliki kemampuan berpikir kritis tinggi yang memperoleh nilai 3 sebesar $51,61 \%$ dan yang memperoleh nilai 4 sebesar $48,39 \%$. Sedangkan persentase siswa dengan kemampuan berpikir kritis rendah yang mendapat nilai 3 sebesar $45,45 \%$ dan yang mendapat nilai 4 sebesar $54,55 \%$. Dari uraian tersebut dapat diketahui bahwa persentase siswa dengan kemampuan berpikir kritis rendah yang mendapat nilai 4 lebih banyak dibandingkan siswa dengan kemampuan berpikir kritis tinggi. Hasil uji statistik non parametrik menunjukkan sig. $(0,625)>\alpha$ $(0,05)$ sehingga dapat disimpulkan bahwa tidak ada pengaruh kemampuan berpikir kritis terhadap perstasi belajar aspek sikap pada materi Ksp.

Berdasarkan Peraturan Menteri Penddikan dan Kebudayaan Republik Indonesia Nomor 104 tahun 2014, sikap bermula dari perasaan yang terkait kecenderungan seseorang dalam merespon suatu objek (Kementerian Pendidikan dan Kebudayaan Republik Indonesia, 2014). Sedangkan berpikir kritis adalah cara berpikir dengan cara menguji, menghubungan dan mengevaluasi semua aspek dari suatu masalah dimana di dalamnya terdapat kemampuan mengumpulkan informasi, mengingat, menganalisis situasi, membaca, memahami, dan mengidentifkasi halhal yang diperlukan (Krulik \& Rudnick, 1999; Shanti, Sholihah, \& Martyanti, 2017; Syahbana, 2012). Dari definisi yang telah diuraikan, tidak ada hubungan secara langsung antara kemampuan berpikir kritis dengan sikap. Berpikir kritis merupakan pola berpikir sedangkan sikap merupakan cerminan perasaan terhadap sesuatu.

Pada prestasi belajar aspek keterampilan, siswa yang memiliki kemampuan berpikir kritis tinggi memperoleh nilai rata-rata 91,45 dan siswa yang memiliki kemampuan berpikir kritis rendah memperoleh nilai rata-rata 90,67. Hasil uji statistik non parametrik menunjukkan sig. $(0,445)>$ $\alpha(0,05)$ sehingga dapat disimpulkan bahwa tidak 
Jurnal Inovasi Pendidikan IPA, 5 (1), 2019 - 16

Siti Khoirun Annisak, Nurma Yunita Indriyanti, Bakti Mulyani

ada pengaruh kemampuan berpikir kritis terhadap perstasi belajar aspek keterampilan pada materi Ksp. Hal tersebut dikarenakan siswa yang memiliki kemampuan berpikir kritis tinggi maupun rendah sama-sama dilibatkan secara aktif selama praktikum dan penyusunan laporan, sehingga keduanya memiliki peluang yang sama untuk memperoleh prestasi belajar yang baik. Prestasi belajar keterampilan diukur dari kemampuan bertindak, misalnya kesiapan, meniru, membiasakan, dan mahir. Untuk melakukan halhal tersebut siswa tidak secara langsung memerlukan kemampuan berpikir kritis sehingga kemampuan berpikir kritis tidak berpengaruh pada aspek keterampilan siswa. Penelitian Arifianingsih, Mulyani, \& Utomo (2015) juga menyebutkan bahwa kemampuan berpikir kritis tidak berpengaruh pada prestasi belajar aspek keterampilan pada materi konsep mol.

\section{Hipotesis Ketiga}

Pengujian hipotesis ketiga dilakukan untuk mengetahui interaksi antara penerapan model pembelajaran $\mathrm{CC}$ dan inkuiri terbimbing berdasarkan representasi tetrahedral kimia dengan kemampuan berpkir kritis terhadap prestasi belajar siswa pada materi Ksp. Hasil uji statistik disajikan dalam Tabel 7.

Tabel 7. Hasil Uji Statistik Hipotesis III

\begin{tabular}{lc}
\hline \multicolumn{1}{c}{ Prestasi Belajar } & Sig./Asymp Sig. \\
\hline Pengetahuan & 0,944 \\
Sikap & 0,833 \\
Keterampilan & 0,397 \\
\hline
\end{tabular}

Berdasarkan Tabel 7, hasil uji statistik parametrik pada prestasi belajar aspek pengetahuan menunjukkan nilai Sig. $(0,944)>\alpha(0,05)$ dan hasil uji statistik nonparametrik aspek keterampilan diperoleh sig. $(0,397)>\alpha$ sehingga dapat disimpulkan bahwa tidak ada interaksi antara penerapan model $\mathrm{CC}$ dan inkuiri terbimbing berdasarkan representasi tetrahedral kimia dengan kemampuan berpikir kritis siswa terhadap prestasi belajar aspek pengetahuan dan keterampilan pada materi Ksp. Pada prestasi belajar aspek pengetahuan dan keterampilan, nilai ratarata siswa kelas CC dengan kemampuan berpikir kritis tinggi yaitu 78,928 dan 91,07. Sedangkan untuk siswa kelas CC dengan kemampuan berpikir kritis rendah yaitu 50,833 dan 89,72. Pada siswa kelas inkuiri terbimbing dengan kemampuan berpikir kritis tinggi nilai rata-rata aspek pengetahuan dan keterampilannya yaitu 79,412 dan 91,76 sedangkan siswa kelas CC dengan kemampuan berpikir kritis rendah yaitu
51,00 dan 91,13. Dari nilai rata-rata tersebut menunjukkan tidak adanya perbedaan signifikan antara siswa dengan kemampuan berpikir kritis tinggi maupun rendah pada kelas $\mathrm{CC}$ dan inkuiri terbimbing.

Pada prestasi belajar aspek sikap, persentase siswa kelas CC dengan kemampuan berpikir kritis tinggi yang memperoleh nilai 3 sebesar $57,14 \%$ dan yang memperoleh nilai 4 sebesar 42,86\%. Persentase siswa kelas CC dengan kemampuan berpikir kritis rendah yang memperoleh nilai 3 dan 4, masing-masing sebesar $50 \%$. Persentase siswa kelas inkuiri terbimbing dengan kemampuan berpikir kritis tinggi yang memperoleh nilai 3 sebesar $47,06 \%$ dan yang memperoleh nilai 4 sebesar 52,94\%. Persentase siswa kelas inkuiri terbimbing dengan kemampuan berpikir kritis rendah yang memperoleh nilai 3 sebesar $40 \%$ dan yang memperoleh nilai 4 sebesar $60 \%$. Setelah dilakukan uji statistik non parametrik diperoleh nilai sig. $(0,833)>\alpha$ sehingga disimpulkan bahwwa tidak ada interaksi antara penerapan model pembelajaran $\mathrm{CC}$ dan inkuiri terbimbing berdasarkan representasi tetrahedral kimia dengan kemampuan berpikir kritis siswa terhadap prestasi belajar aspek sikap.

Berdasarkan uji hipotesis yang telah dilakukan menunjukkan bahwa siswa dengan model pembelajaran $\mathrm{CC}$ dan inkuiri terbimbing yang memiliki kemampuan berpikir kritis tinggi maupun rendah memiliki peluang sama untuk mendapatkan prestasi belajar yang baik. Hal tersebut dikarenakan selama pembelajarn pembagian kelompok dilakukan secara heterogen sehingga siswa dengan kemampuan berpikir kritis tinggi dan rendah tergabung menjadi satu kelompok. Terbentuknya kelompok heterogen memberikan peluang yang sama bagi setiap siswa baik yang memiliki kemampuan berpikir kritis tinggi maupun rendah untuk aktif selama pembelajaran. Siswa dengan kemampuan berpikir kritis tinggi secara tidak langsung akan membantu dan memberi dukungan kepada teman sekelompoknya yang belum dapat mengikuti pembelajaran dengan baik. Melalui pembentukan kelompok, siswa secara tidak langsung dituntut untuk mengembangkan kemampuan sosialnya dalam berinteraksi. Hal itu sesuai dengan teori belajar Vygotsky mengenai pemagangan kognitif yang diartikan sebagai proses ketika pembelajar memperoleh keahlian melalui interaksi dengan ahli, baik itu orang dewasa maupun teman sebaya yang lebih maju (Slavin, 2011). 


\section{Penerapan Tetrahedral Kimia dalam Pembelajaran Kimia}

Pada pembelajaran kimia, guru menerapkan representasi tetrahedral kimia yang meliputi level representasi unsur manusia, makroskopis, submikroskopis, dan simbolis. Pada level unsur manusia, materi dikaitkan dengan kejadian yang dapat dijumpai dalam kehidupan seperti pembentukan stalaktit, penyakit gigi berlubang, pembentukan batu ginjal, dan sebagainya. yang disampaikan di awal pembelajaran pada kegiatan apersepsi seperti Gambar 1. Pada level representasi makroskopis, siswa diajak mengamati beberapa kejadian yang dapat terlihat oleh indra seperti pembentukan endapan. Pembelajaran terkait hal tersebut lebih mudah dipahami saat siswa terlibat kegiatan praktikum mengenai hubungan Ksp dengan reaksi pengendapan seperti Gambar 2.

Tabel 8. Perbandingan Pencapaian Siswa pada

Tes Ksp Kelas CC dan Inkuiri Terbimbing

\begin{tabular}{|c|c|c|c|}
\hline \multirow{2}{*}{ No. } & \multirow{2}{*}{ Indikator Kompetensi } & \multicolumn{2}{|c|}{$\begin{array}{c}\text { Persentase } \\
\text { Ketercapaian }(\%)\end{array}$} \\
\hline & & $\mathrm{CC}$ & $\begin{array}{c}\text { Inkuiri } \\
\text { terbimbing }\end{array}$ \\
\hline 1. & $\begin{array}{l}\text { Menjelaskan } \\
\text { kesetimbangan dalam } \\
\text { larutan jenuh atau } \\
\text { larutan garam yang } \\
\text { sukar larut }\end{array}$ & 100 & 96,875 \\
\hline 2. & $\begin{array}{l}\text { Menghubungkan } \\
\text { tetapan hasil kali } \\
\text { kelarutan dengan } \\
\text { tingkat kelarutan atau } \\
\text { pengendapannya }\end{array}$ & 92,18 & 85,9375 \\
\hline 3. & $\begin{array}{l}\text { Menuliskan persamaan } \\
\text { Ksp elektrolit sukar } \\
\text { larut dalam air }\end{array}$ & 65,625 & 68,75 \\
\hline 4. & $\begin{array}{l}\text { Menghitung kelarutan } \\
\text { elektrolit berdasarkan } \\
\text { data harga Ksp atau } \\
\text { sebaliknya }\end{array}$ & 65,625 & 67,7083 \\
\hline 5. & $\begin{array}{l}\text { Menjelaskan pengaruh } \\
\text { ion senama terhadap } \\
\text { kelarutan }\end{array}$ & 48,4375 & 64,0625 \\
\hline 6. & $\begin{array}{l}\text { Menghitung pH larutan } \\
\text { dari harga Ksp }\end{array}$ & 71,875 & 71,875 \\
\hline 7. & $\begin{array}{l}\text { Memperkirakan } \\
\text { terbentuknya endapan } \\
\text { berdasarkan nilai Ksp }\end{array}$ & 46,875 & 51,3393 \\
\hline
\end{tabular}

Pada level submikroskopis, siswa diberikan penjelasan mengenai dimensi molekuler terkait kejadian yang diamati pada dimensi makroskopis. Pada level representasi simbolis, digunakan rumus atau lambang untuk mempermudah penjelasan pada dimensi submikroskopis. Untuk mengetahui penerapan representasi tetrahedral kimia dalam materi Ksp dilakukan observasi oleh dua orang observer yang telah memahami tetrahedral kimia. Untuk mengetahui pencapaian siswa dalam memahami materi Ksp dengan model CC dan inkuiri terbimbing berdasarkan representasi tetrahedral kimia dapat dilihat dari persentase jawaban siswa pada tes aspek pengetahuan pada Tabel 8 .

\section{Penerapan Representasi Tetrahedral Kimia pada Materi Ksp}

Pada penelitian ini, materi Ksp terbagi menjadi sub-materi pendahuluan, hubungan kelarutan dengan hasilkali kelarutan, pengaruh ion senama, hubungan Ksp dengan $\mathrm{pH}$, dan hubungan Ksp dengan reaksi pengendapan.

\section{Pendahuluan}

Sub materi pendahuluan bertujuan untuk mengenalkan siswa dengan definisi kelarutan dan hasilkali kelarutan. Pada sub materi ini, siswa diajak guru untuk mengenal peristiwa yang berkaitan dengan kehidupan, seperti pembentukan stalaktit dan stalakmit pada gua. Kemudian untuk mendapatkan definisi kelarutan, siswa diajak untuk mengamati peristiwa pelarutan gula dan mengenal senyawa elektrolit yang sukar larut seperti perak klorida. Setelah mengetahui senyawa elektrolit sukar larut, siswa diajak untuk menuliskan reaksi kesetimbangannya dan konstanta kesetimbangannya, sehingga pada akhirnya diperoleh yang namanya hasilkali kelarutan. Proporsi level representasi terahedral pada sub materi ini adalah sebagai berikut:

\section{Unsur Manusia}

Level unsur manusia terlihat pada saat siswa diajak mengenal peristiwa yang berkaitan dengan kelarutan dan hasilkali kelarutan pada kehidupan sehari-hari, seperti pembentukan stalakmit, pembentukan batu ginjal, dan proses pembuatan larutan gula.

\section{Unsur Makroskopis}

Unsur makroskopis ditunjukkan dengan adanya perubahan yang dapat diamati seperti terjadinya endapan,dan perubahan warna.

\section{Unsur Submikroskopis dan Simbolis}

Representasi submikroskopis dan simbolis nampak bersamaan saat diberikan pembahasan mengenai reaksi kesetimbangan dari perak kolorida. Selain itu tampak pula pada saat penulisan persamaan hasilkali kelarutan suatu zat.

Pada penyampaian pendahuluan yang terdiri dari fenomena yang berkaitan dengan 
Jurnal Inovasi Pendidikan IPA, 5 (1), 2019 - 18

Siti Khoirun Annisak, Nurma Yunita Indriyanti, Bakti Mulyani

kehidupan, pengertian kelarutan, faktor-faktor yang mempengaruhi kelarutan, dan pengertian hasilkali kelarutan diharapkan siswa mampu menjelaskan kesetimbangan dalam larutan jenuh atau larutan garam yang sukar larut dan menuliskan persamaan Ksp elektrolit yang sukar larut dalam air. Berdasarkan Tabel 6 persentase siswa yang menjawab benar pada soal Ksp dengan indikator kompetensi menjelaskan kesetimbangan dalam larutan jenuh atau larutan garam yang sukar larut dan menuliskan persamaan Ksp elektrolit yang sukar larut dalam air pada kelas CC sebesar $100 \%$ dan $65,625 \%$, sedangkan pada kelas inkuiri terbimbing sebesar $96,875 \%$ dan $68,75 \%$. Hal tersebut tentunya juga dipengaruhi oleh perbedaan kegiatan belajar pada masingmasing kelas.

Pada kelas CC maupun inkuiri terbimbing, pembelajaran dibuka dengan apersepi dimana guru mulai mengenalkan fenomena-fenomena alam yang berkaitan dengan Ksp seperti stalaktit pada gua. Dimana proses pembentukan stalaktit tersebut tentunya dari pengendapan kapur dalam jangka waktu yang lama. Dalam hal ini bahasan tersebut tentunya sudah mencakup level manusia dan makroskopis. Pada pengertian kelarutan, siswa diajak berpikir tentang definisi kelarutan dari proses garam dapur. Apabila garam dapur yang dilarutkan berlebih maka terbentuk endapan. Dalam hal tersebut pembelajaran telah mencakup level makroskopis, dimana siswa dapat mengamati terbentuknya endapan dan siswa mampu mendapatkan definisi kelarutan dengan bantuan ilustrasi tersebut.

Pada bahasan faktor-faktor yang mempengaruhi kelarutan yang meliputi jenis pelarut, suhu, dan pengadukan level representasi yang diterapkan adalah level manusia, makroskopis, dan sub mikroskopis. Pada bahasan ini, siswa diajak mengamati dari kegiatan sehari-hari misalnya pada pembuatan oralit memerlukan garam. Garam tersebut akan lebih cepat larut apabila dalam air panas daripada air es. Selain itu apabila garam yang dilarutkan diaduk dan yang satu tidak diaduk, tentukan akan memberikan hasil berbeda. Garam yang diaduk akan larut dan menimbulkan rasa asin sedangkan garam yang tidak diaduk akan terkumpul di dasar gelas. Pada bagian level representasi yang diterapkan adalah level manusia dan makroskopis. Sedangkan untuk level sub mikroskopis diterapkan pada bahasan jenis pelarut, misalnya yaitu alasan air dan minyak tidak dapat larut.

Pada bahasan pengertian hasil kali kelarutan $(\mathrm{Ksp})$, siswa diberikan contoh mengenai pelarutan garam perak klorida yang merupakan garam elektrolit sukar larut. Lalu selanjutnya diajak berpikir mengenai kemungkinan yang terjadi dari pelarutan tersebut, misalkan terbentuknya endapan ataupun mnegenai proses ionisasi. Untuk menuliskan proses ionisasi tentunya diperlukan simbol-simbol kimia. Pembelajaran tersebut tentunya telah mencakup level makroskopis, submikroskopis, dan simbolis.

Perbedaan pencapaian prestasi siswa pada indikator kompetensi menjelaskan kesetimbangan dalam larutan jenuh atau larutan garam yang sukar larut dimana kelas CC lebih tinggi dibandingkan dengan kelas inkuiri terbimbing dapat dipengaruhi oleh kegiatan belajarnya. Pada kelas $\mathrm{CC}$ ada proses debat dimana siswa mampu mendapat pandangan yang lebih luas dalam mengatasi suatu permasalahan. Selain itu pada kelas $\mathrm{CC}$ diskusi berjalan tidak hanya dalam kelompok tetapi dengan kelompok lain. Sedangkan pada kelas inkuiri terbimbing diskusi lebih ditekankan kelompok itu sendiri dan bukan bersama kelompok lain. Sedangkan pada indikator menuliskan persamaan Ksp elektrolit yang sukar larut dalam air, capaian prestasi kelas inkuiri terbimbing lebih tinggi dibandingkan kelas CC. Hal tersebut karena pada kelas inkuiri guru memandu siswa sehingga siswa mendapatkan satu kejelasan. Sedangkan pada kelas CC yang melibatkan debat, dikhawatirkan ketika menuliskan persamaan masih terbawa pendapat awal dan bukan pendapat akhir hasil diskusi.

\section{Hubungan Kelarutan dan Hasil Kali Kelarutan}

Pada sub materi ini, lebih banyak melibatkan level sub mikroskopis dan simbolis. Hal tersebut karena dalam hubungan kelarutan dan hasilkali kelarutan lebih banyak membahas proses ionisasi suatu senyawa kemudian melibatkan lambang-lambang untuk mempermudah penjelasannya.

Pada penyampaian bahasan ini diharapkan siswa mampu menghubungkan tetapan hasil kali kelarutan dengan tingkat kelarutan dan pengendapannya dan menghitung kelarutan elektrolit berdasarkan data harga Ksp atau sebaliknya. Berdasarkan Tabel 6 persentase siswa yang menjawab benar pada soal Ksp dengan indikator kompetensi menghubungkan tetapan hasil kali kelarutan dengan tingkat kelarutan dan pengendapannya dan menghitung kelarutan elektrolit berdasarkan data harga Ksp atau sebaliknya pada kelas CC sebesar $92,18 \%$ dan $65,625 \%$, sedangkan pada kelas inkuiri terbimbing sebesar $85,9375 \%$ dan $67,7083 \%$. 
Pada penyampaian hubungan kelarutan dengan hasil kali kelarutan, level representasi yang ditekankan yaitu submikroskopis dan simbolis. Pada pembelajaran ini siswa belajar mengenai hal yang terjadi dalam larutan jenuh, dimana melibatkan reaksi kesetimbangan. Reaksi kimia tersebut dituliskan menggunakan simbolsimbol kimia. Sehingga dalam penyampaian materi ini observer juga memberikan penilaian bahawa level representasi yang dikaitkan hanya pada submikroskopis dan simbolis.

Perbedaan pecapaian hasil tes materi Ksp pada kelas CC dan inkuiri terbimbing dikarenakan siswa pada kelas CC lebih banyak melakukan diskusi baik dengan teman dalam satu kelompoknya maupun kelompok yang lain, sehingga mereka memperoleh pendapat dari berbagai sudut pandang untuk memperoleh pendapat akhir. Pada kelas inkuiri terbimbing, siswa hanya berdiskusi dengan teman kelompoknya kemudian mendengarkan keterangan guru, sehingga siswa belum mendapatkan pengalaman untuk memperoleh pendapat dari berbagai sudut pandang. Padahal, sering dijumpai ketika siswa belum mengerti tetapi malu untuk bertanya sehingga pencapaian yang dicapai kurang maksimal.

\section{Pengaruh Ion Senama}

Pada sub materi ini, guru pertama-tama menampilkan gambar sidik jari (level manusia). Dari gambar yang ditampilkan siswa diajak untuk menyebutkan kaitannya dengan materi yang dibahas. Setelah mengetahui bahwa hal tersebut berhubungan dengan penambahan ion sejenis, lalu siswa diajak memahami akibat yang terjadi dari penambahan ion sejenis yang berlebih (level makroskopis). Dari adanya kejadian pada level makroskopis, siswa diajak untuk lebih memahami materi dengan menggunakan persamaan reaksi kimia yang dituliskan dalam bentuk lambang-lambang kimia (level submikroskopis dan simbolis). Sehingga bahasan pada sub materi ini mencakup keempat level representasi kimia.

Pada penyampaian bahasan ini diharapkan siswa mampu menjelaskan pengaruh ion senama terhadap kelarutan. Berdasarkan Tabel 6 persentase siswa yang menjawab benar pada soal Ksp dengan indikator kompetensi menjelaskan pengaruh ion senama terhadap kelarutan pada kelas CC sebesar 48,4375\%, sedangkan pada kelas inkuiri terbimbing sebesar 64,0625\%.

Hubungan Ksp dengan $\mathrm{pH}$

Pada sub materi ini, guru pada awalnya menunjukkan keterkaitan masalah gigi berlubang terhadap Ksp dan pH (level manusia). Selanjutnya siswa diberikan masalah mengenai keterkaitan Ksp dengan $\mathrm{pH}$ (makroskopis). Dari materi sebelumnya (asam basa) yang telah membahas $\mathrm{pH}$, siswa diajak untuk menentukan $\mathrm{pH}$ suatu larutan yang diketahui harga Ksp nya dengan melibatkan persamaan reaksi dan lambang-lambang kimia (sub mikroskopis dan simbolis).

Pada penyampaian bahasan ini diharapkan siswa mampu menghitung $\mathrm{pH}$ larutan dari harga Ksp. Berdasarkan tabel 6 persentase siswa yang menjawab benar pada soal Ksp dengan indikator kompetensi menghitung $\mathrm{pH}$ larutan dari harga Ksp pada kelas CC sebesar $71,875 \%$, sedangkan pada kelas inkuiri terbimbing sebesar $71,875 \%$. pada bahasan ini capaian prestasi yang didapatkan baik dari kelas CC maupun dari kelas inkuiri terbimbing sama. Ternyata penggunaan representasi tetrahedral kimia dapat membantu siswa dalam memahami materi meskipun model pembelajaran yang digunakan berbeda.

\section{Hubungan Ksp dengan Reaksi Pengendapan}

Guru pada awalnya memberi tahu fungsi dari reaksi pengendapan, yaitu untuk memisahkan suatu senyawa dengan senyawa lain dan untuk keperluan analisis awal. Selanjutnya guru memberi contoh alat yang berguna untuk memisahkan zat, yaitu centrifuge (unsur manusia). Pada sub materi ini dilakukan praktikum, maka untuk level makroskopis siswa dapat menemukannya melalui terbentuknya endapan setelah mereaksikan senyawa. Sedangkan untuk level submikroskopis dan simbolis, dapat dilihat saat siswa membandingkan hasil percobaan dengan perhitungan yang mereka lakukan, dimana perhitungan tersebut melibatkan simbol-simbol.

Pada penyampaian bahasan ini diharapkan siswa mampu memperkirakan terbentuknya endapan berdasarkan nilai Ksp. Berdasarkan Tabel 6 persentase siswa yang menjawab benar pada soal Ksp dengan indikator kompetensi memperkirakan terbentuknya endapan berdasarkan nilai Ksp pada kelas CC sebesar 46,875\%, sedangkan pada kelas inkuiri terbimbing sebesar $51,3393 \%$. Pada bahasan ini capaian prestasi yang didapatkan kelas CC lebih rendah dibandingkan kelas inkuiri terbimbing.

Selama proses pembelajaran, materi dikaitkan dengan representasi tetrahedral kimia. Pada materi Ksp yang meliputi pendahuluan, hubungan kelarutan dengan hasil kelarutan, pengaruh ion senama, hubungan $\mathrm{Ksp}$ dengan $\mathrm{pH}$, dan hubungan Ksp dengan reaksi pengendapan, 
secara umum pembelajaran lebih banyak mencakup level submikroskopis dan simbolis meskipun pada sub bahasan tertentu keempat level representasi dapat diterapkan secara bersamaan.

\section{Perbedaan Pembelajaran Kimia Materi Ksp pada Kelas CC dan Kelas Inkuiri Terbimbing}

Penyampaian materi Ksp berdasrkan representasi tetrahedral kimia dilakukan dengan menggunakan model pembelajaran $\mathrm{CC}$ dan inkuiri terbimbing. Sintaks pembelajaran CC yaitu: (a) mengajukan pertanyaan; (b) menempatkan siswa dalam kelompok; (c) mengajukan pendapat; (d) mengomentari persepsi kelompok lain; (e) memahami perspektif lain; (f) merekonseptualisasi dan menyimpulkan. Sedangkan untuk sintaks pembelajaran inkuiri terbimbing yaitu: (a) orientasi; (b) merumuskan masalah; (c) mengajukan hipotesis; (d) mengumpulkan data; (e) menguji hipotesis; (f) menyimpulkan. Pada kedua model tersebut yang membedakan adalah tingkat aktivitas siswa. Pada model CC siswa dituntut untuk lebih aktif dengan peran guru yang ledih sedikit apabila dibandingkan dengan model inkuiri terbimbing.

Pada model pembelajaran inkuiri terbimbing, siswa belajar merumuskan masalah yang ada. Hal tersebut berbeda dengan model CC dimana siswa langsung diberikan permasalahan. Oleh karena itu siswa dengan model pembelajaran inkuiri terbimbing memiliki pemahaman soal yang lebih baik dibandingkan dengan siswa yang menggunaan model CC. Pada materi Ksp siswa dituntut untuk menguasai cara menuliskan reaksi ionisasi dan berhitung, sehingga lebih banyak melibatkan siswa pada level representasi submikroskopis dan simbolis. Siswa dengan model pembelajaran inkuiri terbimbing yang mendapat perhatian guru lebih banyak dari model yang lain memiliki pemahaman level representasi submikroskopis dan simbolis yang lebih baik. Hal tersebut dibuktikan dengan lebih tingginya persentase ketercapaian prestasi belajar pada indikator kompetensi 3, 4, 5, dan 7 apabila dibandingkan dengan kelas CC. Apabila hasil tingkat ketercapain prestasi belajar dirata-rata dapat terlihat bahwa kelas inkuiri terbimbing memiliki pemahaman lebih tinggi dibandingkan dengan kelas CC.

Pada pembelajaran CC, proses pembelajaran yang berlangsung dinilai kurang efektif dikarenakan siswa ada yang kurang aktif dan ragu-ragu menyampaikan pendapatnya. Adanya kejadian tersebut tentunya mempengaruhi tingkat pemahaman siswa terhadap materi. Meskipun persentase pencapaian prestasi belajar dari kelas $\mathrm{CC}$ dan inkuiri terbimbing berbeda, namun penggunaan representasi tetrahedral kimia membantu siswa memahami materi dengan mengetahui level reprensentasinya.

\section{SIMPULAN}

Berdasarkan penelitian disimpulkan bahwa: (1) tidak ada pengaruh penerapan model pembelajaran $\mathrm{CC}$ dan inkuiri terbimbing berdasarkan representasi tetrahedral kimia terhadap prestasi belajar aspek pengetahuan, sikap, dan keterampilan pada materi Ksp. (2) ada pengaruh kemampuan berpikir kritis terhadap prestasi belajar aspek pengetahuan pada materi Ksp. Akan tetapi tidak ada pengaruh kemampuan berpikir kritis terhadap prestasi belajar aspek sikap dan keterampilan. (3) Tidak ada interaksi antara penerapan model pembelajaran $\mathrm{CC}$ dan inkuiri terbimbing berdasarkan representasi tetrahedral kimia dengan kemampuan berpikir kritis pada materi Ksp terhadap prestasi belajar aspek pengetahuan, sikap, dan keterampilan.

\section{DAFTAR PUSTAKA}

Arifah, K. N., Haryono, H., \& Nurhayati, N. D. (2015). Upaya peningkatan keaktifan siswa dan prestasi belajar dengan metode constructive controversy (CC) pada materi elektrolit dan non elektrolit bagi peserta didik kelas X MIA 2 semester genap SMA Batik 2 Surakarta tahun pelajaran 2013/2014. Jurnal Pendidikan Kimia $(J P K), \quad 4(2)$, 122-129. Retrived from https://jurnal.fkip.uns.ac.id/index.php/kim $\mathrm{ia} /$ article/view/5778

Arifianingsih, I., Mulyani, S., \& Utomo, S. B. (2015). Pengaruh pembelajaran problem solving berbantuan tutor sebaya dan team assisted individualization (TAI) dengan memperhatikan kemampuan berpikir kritis terhadap prestasi belajar siswa. Jurnal Pendidikan Kimia, 4(4), 163-172. Retrived from https://jurnal.fkip.uns.ac.id/index.php/kim ia/article/view/6640

BSNP. (2015). Laporan hasil ujian nasional. Retrieved from. http://118.98.234.50/ lhun/daya_serap.aspx

Chittleborough, G., \& Treagust, D. F. (2007). The modelling ability of non-major chemistry students and their understanding of the sub-microscopic level. Chemistry 
Jurnal Inovasi Pendidikan IPA, 5 (1), 2019 - 21

Siti Khoirun Annisak, Nurma Yunita Indriyanti, Bakti Mulyani

education research and practice, 8(3), 274-292.

https://doi.org/10.1039/b6rp90035f

Faizah, F., Miswadi, S. S., \& Haryani, S. (2013). Pengembangan perangkat pembelajaran berbasis masalah untuk meningkatkan soft skill dan pemahaman konsep. Jurnal Pendidikan IPA Indonesia, 2(2). doi:https://doi.org/10.15294/jpii.v2i2.271 2

Gregory, R. J. (2004). Psychological testing: History, principles, and applications. Allyn \& Bacon.

Hamdani. (2011). Strategi belajar mengajar. Bandung: Pustaka Setia

Hofreiter, T. D., Monroe, M. C., \& Stein, T. V. (2007). Teaching and evaluating critical thinking in an environmental context. Applied Environmental education and communication, 6(2), 149-157. doi: https://doi.org/10.1080/153301507015981 97

Indah, Y., \& Azizah, U. (2014). Penerapan model pembelajaran inkuiri terbimbing dengan pendekatan saintifik pada materi pokok larutan elektrolit dan non elektrolit kelas X MIA 5 SMAN 3 Surabaya. UNESA Journal of Chemical Education, 3 (3), 105111. Retrived from https://jurnalmahasiswa.unesa.ac.id/index. php/journal-of-chemicaleducation/article/view/9751

Johnstone, A. H. (2000). Teaching of chemistrylogical or psychological?. Chemistry Education Research and Practice, 1(1), 915. doi:https://doi.org/10.1039/A9RP90001B

Kementerian Pendidikan dan Kebudayaan Republik Indonesia. (2013). Peraturan Menteri Pendidikan dan Kebudayaan Nomor 65 Tahun 2013 tentang standar proses untuk satuan pendidikan dasar dan menengah..

Kementerian Pendidikan dan Kebudayaan Republik Indonesia. (2014). Peraturan Menteri Pendidikan dan Kebudayaan Nomor 104 Tahun 2014 tentang penilaian hasil belajar oleh pendidik pada pendidikan dasar pendidikan menengah.

Krulik, S., \& Rudnick, J. A. (1999). Innovative tasks to improve critical and creative thinking skills. from Developing
Mathematical reasoning in Grades $K-12$, 138-145.

Kulsum, U. (2013). Rendahnya kualitas pendidikan di Indonesia. Retrieved from http://jurnalilmiahtp2013.blogspot.com/20 13/12/rendahnya-kualitas-pendidikandi29.html

Kurnianto, H., Masykuri, M., \& Yamtinah, S. (2016). Pengaruh model pembelajaran discovery learning disertai lembar kegiatan siswa (LKS) terhadap prestasi belajar siswa pada materi hidrolisis garam kelas XI SMA Negeri Karanganyar tahun pelajaran 2014/2015. Jurnal Pendidikan Kimia, 5(1), 1-15. Retrived from https://jurnal.fkip.uns.ac.id/index.php/kim ia/article/view/6913

Magdalena, O., Mulyani, S., \& Van Hayus, E. S. (2014). Pengaruh pembelajaran model problem based learning dan inquiry terhadap prestasi belajar siswa ditinjau dari kreativitas verbal pada materi hukum dasar kimia kelas X SMAN 1 Boyolali tahun pelajaran 2013/2014. Jurnal Pendidikan Kimia, 3(4), 162-169. Retrived from https://jurnal.fkip.uns.ac.id/index.php/kim $\mathrm{ia} /$ article/view/4617

Mahaffy, P. (2004). The future shape of chemistry education. Chemistry Education Research and Practice, 5(3), 229-245. doi:https://doi.org/10.1039/B4RP90026J

Mahaffy, P. (2006). Moving chemistry education into 3D: A tetrahedral metaphor for understanding chemistry. Union Carbide Award for Chemical Education. Journal of Chemical Education, 83(1), 49-55. https://doi.org/10.1021/ed083p49

Mawarsari, A. A. (2013). Penerapan metode eksperimen berpendekatan inkuiri pada materi larutan penyangga untuk meningkatkan pemahaman konsep sikap ilmiah siswa. Thesis. Universitas Negeri Semarang

Mindtools. (2011). Constructive controversy. Retrieved from http://www.mindtools. com/pages/article/newTMC_71.html.

Muhardi, M. (2004). Kontribusi pendidikan dalam meningkatkan kualitas bangsa Indonesia. Mimbar: Jurnal Sosial dan Pembangunan, 20(4), 478-492.

Pusporini, S., Ashadi, A., \& Sarwanto, S. (2012). Pembelajaran kimia berbasis problem solving menggunakan laboratorium riil 
Jurnal Inovasi Pendidikan IPA, 5 (1), 2019 - 22

Siti Khoirun Annisak, Nurma Yunita Indriyanti, Bakti Mulyani

dan virtuil ditinjau dari gaya belajar dan kemampuan berpikir kritis siswa. Jurnal Inkuiri, 1(1), 34-43. Retrived from https://jurnal.fkip.uns.ac.id/index.php/snp s/article/view/5064

Rybczynski, S. M., \& Schussler, E. E. (2013). Effects of instructional model on student attitude in an introductory biology laboratory. International Journal for the Scholarship of Teaching and Learning, 7(2), n2. doi: https://doi.org/10.20429/ijsotl.2013.07022 2

Sanjaya, W. (2013). Penelitian pendidikan, jenis, metode dan prosedur. Jakarta: Kencana Prenada Media Group.

Shanti, W. N., Sholihah, D. A., \& Martyanti, A. (2017). Meningkatkan kemampuan berpikir kritis melalui problem posing. LITERASI (Jurnal Ilmu Pendidikan), 8(1), 48-58.

Slavin, R.E., (2011). Psikologi pendidikan: Teori dan praktik. Jakarta: PT Indeks Permata Puri Media.

Sulistyowati, N., Suyatno, M. S., \& Poedjiastoeti, S. (2014). Pembelajaran kimia dengan model learning cycle 5E untuk meningkatkan penguasaan konsep dan keterampilan berfikir kritis siswa SMK pada pokok bahasan termokimia. In Jurnal Prosiding Seminar Nasional Kimia (pp. 107-114). FMIPA Universitas Negeri Surabaya.

Syahbana, A. (2012). Pengembangan perangkat pembelajaran berbasis kontekstual untuk mengukur kemampuan berpikir kritis matematis siswa SMP. EDUMATICA Jurnal Pendidikan Matematika, 2(02).

Utami, W. D., Dasna, I., \& Sulistina, O. (2013). Pengaruh penerapan model pembelajaran inkuiri terbimbing terhadap hasil belajar dan keterampilan proses sains siswa pada materi kelarutan dan hasil kali kelarutan. Jurnal Penelitian Pendidikan FKIP Universitas Negeri Malang, 4 (2), 190-198

Vollmer, A. \& Seyr, S. (2012) Constructive controversi in innovation processesapplication and evaluation. Intl. Association for Conflict Management, IACM 25th Annual Conference. Retrieved from https://papers.ssrn.com /sol3/papers.cfm?abstract_id=2084761. 